総 氞总

\title{
卵及び卵加工品におけるサルモネラエンテリティディス の污染とその対策
}

品川 邦 汎*

\author{
Contamination of Salmonella Enteritidis in Hen Eggs and \\ Egg-Products and Its Control
}

\author{
Kunihiro SHINAGawa \\ (Department of Veterinary Microbiology, Faculty of Agriculture, Iwate University: \\ 3-18-8, Ueda, Morioka-shi, Iwate 020-8550, Japan)
}

我が国における鶏卵生産量は 257 万トン（平成 8 年） で，その消費形態としては，一般家庭用のものが最む多 く全体の 52.3\% を占めており，このほかレストラン， ホテル・旅館, 給食施設などで使われる業務用殼付卵が $26.6 \%$ である. 更に, 液卵として加工用に使用されて いるものが $21.1 \%$ で，この加工用は年々増加の傾向を 示している (平成 8 年鶏卵流通統計による).

我が国では, 古くから卵は安全で栄養化の高い食品と して, 病人, 老人及び虚弱体質の人を初めとし, 一般の 人々に生卵として食されている。しかし，1980年代の 中頃から欧米諸国，特に英国，フランス，北ヨーロッパ 諸国及び米国において「卵およびその加工品」による Salmonella Enteritidis（SEと略）食中毒事件が急増 してきた1),2).また, 我が国でも1988年に, 錦糸卵に より患者数 10,476 名と最大規模のサルモネラ (S. Typhimurium) 食中毒事件 ${ }^{3)}$ が発生し，この年には患者数 が激増した. 更に 1990 年以後, サルモネラ（特にSE） による食中毒事件及び患者数が増加し始め, 1991 年に はそれまで第 1 位の患者数を示していた腸炎ビブリオ 食中毒を抜いて最む多く発生し，また 1992 年には事件 数であ第 1 位を示すようになった，それ以後，本食中 毒は発生件数及び患者数と屯毎年第 1,2 位を示してい る4). それらの事例の多くは「卵及び卵加工品」による あのであり, 農場でのニワトリの飼養管理及び農場（生 産）から消費における鶏卵の取り扱い，更に液卵の製造 及び卵加工品 (卵調理食品) 等の衛生管理等について, その重要性が強く指摘されてきた.

本稿では, 卵の衛生管理, 特に農場から鶏卵格付選

\footnotetext{
* 岩手大学農学部： T020-8550 岩手県盛岡市上田 3-18-8
}

別・包装センター（GP センター）及び液卵製造（割卵 工場）の実態とその衛生管理（特に SE の污染対策）を 中心に述べる.

\section{I. サルモネラ食中毒の発生状況}

\section{1. 諸外国及び我が国における発生状況}

1985 年以降, 世界各国で鶏卵による $S E$ 食中毒が多 発し始め, ヨーロッパでは 1982 年から 88 年にかけて $S E$ 分離例数は 14 倍に増加した ${ }^{5)} .1989$ 年 3 月 WHO において「鶏におけるサルモネラ $(S E)$ 污染に関する疫 学と防除対策」について緊急会議が開催され, 各国の現
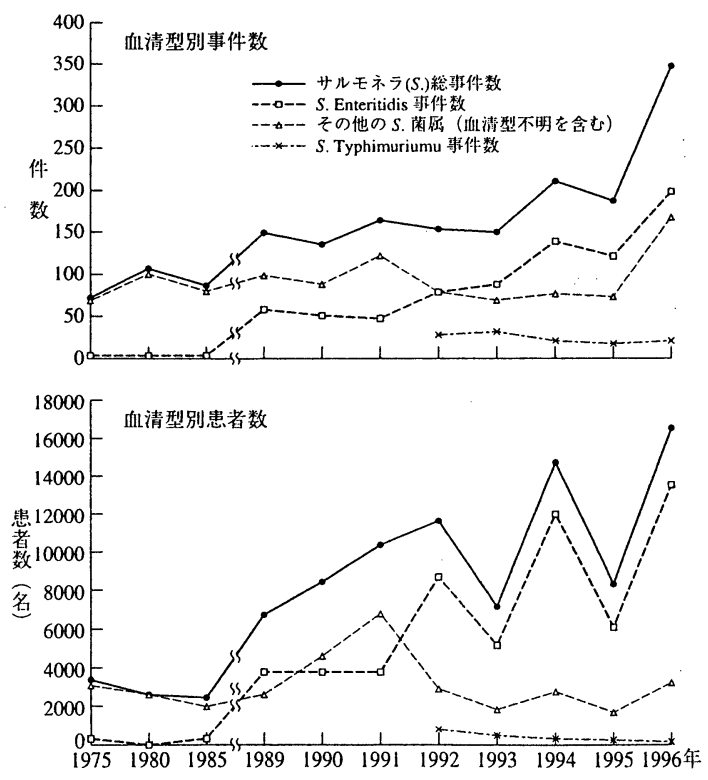

図 1. 我が国におけるサルモネラ食中毒の発生状況 
表 1. サルモネラ各血清による食中毒発生状況

\begin{tabular}{|c|c|c|c|c|c|c|c|c|}
\hline \multirow[b]{2}{*}{$\mathrm{O}$ 群 } & \multicolumn{2}{|l|}{1993 年 } & \multicolumn{2}{|l|}{1994 年 } & \multicolumn{2}{|l|}{1995 年 } & \multicolumn{2}{|c|}{1996 年(速報による) } \\
\hline & 血清型 & 事件数 & 血清型 & 事件数 & 血清型 & 事件数 & 血清型 & 事件数 \\
\hline \multirow[t]{5}{*}{$\mathrm{O} 4$} & S. Typhimurium & $\begin{array}{c}11 \\
(15 \%)\end{array}$ & S. Typhimurium & $\begin{array}{r}5 \\
(5 \%)\end{array}$ & S. Typhimurium & $\begin{array}{c}5 \\
(5 \%)\end{array}$ & S. Typhimurium & $\begin{array}{c}4 \\
(4 \%)\end{array}$ \\
\hline & S. Haifa & 4 & S. Paratyphi B & 3 & S. Chester & 1 & S. Heidelberg & 3 \\
\hline & S. Paratyphi B & 1 & S. Stanley & 1 & & & & \\
\hline & S. Stanley & 1 & & & & & & \\
\hline & 型不明 & 1 & 型不明 & 4 & 型不明 & 1 & & \\
\hline \multirow[t]{6}{*}{ O7 } & S. Thompson & 4 & S. Singapore & 2 & S. Infantis & 5 & S. Montevideo & 2 \\
\hline & S. Potsdam & 1 & S. Thompson & 1 & S. Montevideo & 2 & S. Singapore & 2 \\
\hline & S. Virchow & 1 & $S$. Infantis & 1 & S. Thompson & 1 & $S$. Infantis & 1 \\
\hline & & & & & S. Virchow & 1 & S. Virchow & 1 \\
\hline & & & & & S. Braenderup & 1 & S. Thompson & 1 \\
\hline & 型不明 & 2 & 型不明 & 2 & 型不明 & 1 & 型不明 & 1 \\
\hline \multirow[t]{3}{*}{$\mathrm{O} 8$} & S. Litchfield & 1 & S. Litchfield & 1 & S. Hadar & 3 & S. Litchfield & 1 \\
\hline & & & S. Hadar & 1 & S. Litchfield & 1 & S. Hadar & 1 \\
\hline & & & 型不明 & 1 & & & & \\
\hline \multirow[t]{3}{*}{ O9 } & S. Enteritidis & $\begin{array}{c}41 \\
(55 \%)\end{array}$ & $S$. Enteritidis & $\begin{array}{c}75 \\
(70 \%)\end{array}$ & S. Enteritidis & $\begin{array}{c}69 \\
(71 \%)\end{array}$ & S. Enteritidis & $\begin{array}{c}84 \\
(77 \%)\end{array}$ \\
\hline & S. Dublin & 1 & & & S. Dublin & 1 & & \\
\hline & 型不明 & 5 & 型不明 & 7 & 型不明 & 4 & 型不明 & 6 \\
\hline 03,10 & & & S. Weltevreden & 3 & S. Weltevreden & 1 & S. Anatum & 1 \\
\hline \multirow[t]{2}{*}{$\mathrm{O} 16$} & S. Gaminara & 1 & & & & & 型複数分離* & 1 \\
\hline & $\begin{array}{c}\text { 計 } \\
(\%)\end{array}$ & $\begin{array}{c}75 \\
(100 \%)\end{array}$ & & $\begin{array}{c}107 \\
(100 \%)\end{array}$ & & $\begin{array}{c}97 \\
(100 \%)\end{array}$ & & $\begin{array}{c}109 \\
(100 \%)\end{array}$ \\
\hline
\end{tabular}

* S. Infantis (5); S. Tennessee (1); S. Enteritidis (14); S. Eastboume (3) （血清型別事件数：患者数 10 名以上，病原微生物検出情報の速報による）

表 2. 各国における $S$. Enteritidis ファージ型分布

\begin{tabular}{|c|c|c|c|c|c|c|}
\hline ファージ型 & $\begin{array}{c}\text { 日本 } \\
(1989 \sim 95)^{* 1}\end{array}$ & $\begin{array}{c}\text { 米国 } \\
(1985 \sim 93)^{* 1}\end{array}$ & $\begin{array}{c}\text { 英国 } \\
(1993,7 \sim 9)^{* 1}\end{array}$ & $\begin{array}{c}\text { オーストリア } \\
(1990 \sim 93)\end{array}$ & $\begin{array}{c}\text { オランダ } \\
(1989 \sim 92)\end{array}$ & $\begin{array}{c}\text { オーストラリア } \\
\text { (1991〜93) }\end{array}$ \\
\hline 1 & $138(28)^{* 3}$ & - & 3 & $1,966(5)$ & $2,342(84)$ & - \\
\hline 2 & - & 8 & - & - & 119 & - \\
\hline 3 & 5 & - & - & - & 16 & - \\
\hline 4 & $172(35)$ & 4 & $46(81)$ & $29,627(77)$ & 10 & $156(45)$ \\
\hline 6 & 1 & - & 2 & - & 55 & - \\
\hline 8 & 22 & $148(54)$ & 1 & $3,767(10)$ & 3 & - \\
\hline 9 & 15 & - & - & - & 1 & - \\
\hline 11 & - & - & - & - & 2 & - \\
\hline 13 & - & 14 & - & - & - & - \\
\hline $13 a$ & 2 & $58(21)$ & - & - & - & - \\
\hline $14 \mathrm{~b}$ & 1 & 11 & - & - & - & - \\
\hline 24 & - & - & 1 & - & - & - \\
\hline 26 & - & - & - & - & - & $93(27)$ \\
\hline 34 & $90(18)$ & 4 & - & - & - & - \\
\hline $\operatorname{Mix}$ & 23 & 16 & - & - & - & - \\
\hline 他*2 & 18 & 13 & 4 & 3,262 & 240 & 101 \\
\hline 計 & $487(100)$ & $276(100)$ & $57(100)$ & $38,622(100)$ & $2,788(100)$ & $350(100)$ \\
\hline
\end{tabular}

*1: 集団事例数, $* 2$ ：型別不能を含む， *3：( ) 内は\%

中村 ${ }^{11)}$ : 臨床之微生物より引用. 
表 3. 卵及び卵料理による S. Enteritidis 食中毒

\begin{tabular}{|c|c|}
\hline 原因食品 & 発生件数 (患者数) \\
\hline \multicolumn{2}{|l|}{ 卵料理（生） } \\
\hline マヨネーズ & $9(1,309)$ \\
\hline 洋菓子 & $19(2,717)$ \\
\hline アイスクリーム & $5(938)$ \\
\hline 卵納豆 & $8(409)$ \\
\hline とろろ & $7(284)$ \\
\hline まぐろ山かけ & $1(11)$ \\
\hline \multicolumn{2}{|l|}{ 卵料理（加熱） } \\
\hline 卵焼き & $5(1,066)$ \\
\hline 錦糸卵 & $3(281)$ \\
\hline オムレツ & $7(175)$ \\
\hline 卵納豆 & $1(32)$ \\
\hline だし巻き & $6(194)$ \\
\hline 卵とじ & $5(128)$ \\
\hline 目玉焼き & $1(32)$ \\
\hline 茶碗蒸し & $2(71)$ \\
\hline \multicolumn{2}{|l|}{ 卵料理 加熱複合 } \\
\hline 魚介類の煮物, 焼物, 揚げ物 & $19(1,279)$ \\
\hline サンドイッチ & $4(328)$ \\
\hline 調理パン & $3(159)$ \\
\hline そば（具） & $3(608)$ \\
\hline 卵入りどんぶり & $8(1,580)$ \\
\hline コロッケ & $1(24)$ \\
\hline サラダ & $3(1,818)$ \\
\hline 給食（原料：鶏卵，液卵） & $2(78)$ \\
\hline 鳥肉（加熱したもの） & $3(177)$ \\
\hline
\end{tabular}

「病原微生物検出状況の集団事例に関する速報」,

調查年：1989 1997 年（伊藤 ${ }^{14)}$ の成績に追加）

状把握並に今後の防止対策などが論議された ${ }^{6), 7)}$. しか し，十分な予防対策はなく，その後む本食中毒事件は減 少を示すことなく, 各国で多数の患者が発生しており, 今日世界で最も発生頻度の高い食中毒 (foodborne disease) の一つである. 一方，我が国では平成元年（1989 年）に突如として SE による食中毒が多発し，その発生 件数（146 事例）は例年の 2 倍近くに増加し, 平成 4 年（1992 年）には食中毒事件数の中で第 1 位を示すよ うになっだ)。サルモネラ食中毒患者数の約 $80 \%$ 以上 が SEによるものであり，また 1995 年以後本菌による 死者屯毎年発生している ${ }^{8)}$. 我が国におけるサルモネラ 食中毒のうち, 本菌の各血清型（SEとその他の型）に よる発生件数及び患者数を図 1 に示す.

\section{2. サルモネラの血清型とファージ型}

サルモネラ食中毒のうち SE（患者数 10 名以上）に よる事件は，93 年 41 件 (54\%) で，それ以後は毎年 69 〜84 件 (71〜 76\%) の発生を示している. また 1988 年 以前, 最も多く発生を示していた $S$. Typhimurium 食 中毒は減少しており, 毎年数件の発生である（表 1). しかし近年, 欧米諸国では SEに変りS.Typhimu- rium による発生が増加傾向を示し，しかもこれらの多 くは抗生物質の多剂耐性を示すむのである ${ }^{9}$. 他方, 家 庭内などで発生する散発事例から分離されるサルモネラ でもSE が最む多く，毎年 $40 \sim 60 \%$ を占めている ${ }^{10)}$.

食中毒事例から分離される $S E$ のファージ型（14 種 のファージにより 47 型に細分される）には特徵があ り，我が国で高頻度に分離されるファージ型 (PT) 4 及 び PT1（1992 年以後に増加）は, オランダ, 英国及び オーストラリアで多く見られている（表2）。しかし， 1989～1991 年に多く見られたPT34（1990 年には分 離株の 69\% を占める）によるものは減少し，1995〜 1996 年にはほとんど発生がなくなった ${ }^{11)}$.なお，米国 及びカナダでは PT8 と PT13 が多く分離されている ${ }^{12)}$.

\section{3. 原因食品と原因施設}

サルモネラ食中毒（1986～1995 年に発生した $S E$ 食 中毒 380 件）において, 原因食品が特定されたものは 45\% で，そのうち鶏卵使用によるあのが $57 \%$ であっ た ${ }^{13)}$. 1989 1997 年までの「卵及び卵加工品（卵料理 食品)」によるサルモネラ (SE) 食中毒の発生件数（患者 数 10 名以上の事例）を表 3 に示す. 生卵によるものが 最む多く 49 件で，加熱した卵料理 30 件，卵を用いた 料理（又は複合料理）が 35 件であった ${ }^{14)}$. このほか, 卵及び卵加工品によると推定されたものを入れると約 90\% が殼付卵によるあのであり, 液卵によるあのはわ ずか $2 \%$ 程度である ${ }^{15)}$ ．また，本食中毒の発生原因施 設は飲食店が最も多く $32 \%$, 次いで集団給食施設 $22 \%$ ，この他弁当給食施設，家庭などの $15 \%$ であ $3^{13), 16)}$.

\section{4. ヒトへの SE 発症菌量}

サルモネラ食中毒の発症菌量は, ヒトが $10^{5} \mathrm{cfu}$ （個）以上摂取した場合に発症すると言われていたが, 近年 $S E$ 食中毒の原因食品の残品（又は同一製品）など の検查成績から，その菌量は数個～ $10^{2} \mathrm{cfu} /$ ヒトであ発 症することが報告されている ${ }^{17)}$. 更に, これらの事例で は原因食品 $(\mathrm{SE})$ を摂取し発症するまでの潜伏期は, こ れまで一般に言われているサルモネラ食中毒の潜伏期 $12 \sim 48$ 時間（平均 18〜24 時間）に対し，長時間（30 〜36 時間）であることあ知られており，これは原因食 品中の菌数が少ないことによると推定されている ${ }^{18)}$.

\section{II. 殻付卵の衛生管理}

1. 鶏卵の処理, 流通

1) GP センターでの卵処理

全国の各農場で生産される鷄卵（年間約 260 万トン） の約 79\% は, GP センタ - (Grading and Packing Center) に搬入されている.

農場で採取された卵は, 専用のコンテナートレイある いはダンボール箱に詰め GP センターに搬入される．ま た, 農場によっては GP センターに直結した自動コンベ アーベルトで定期的に搬入するシステム（インライン方・ 


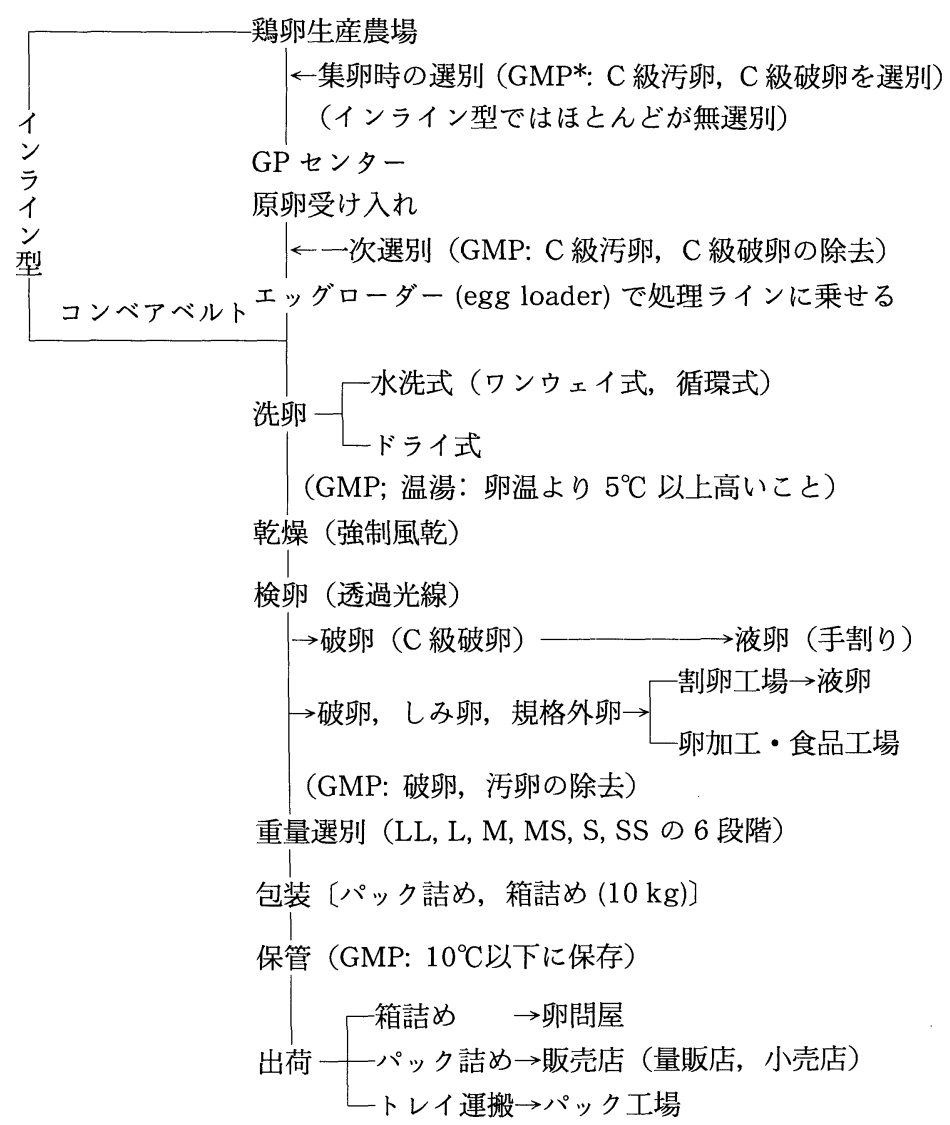

図 2. GP センターにおける鶏卵の処理工程

*GMP: 卵生産のための一般的衛生管理

式）を導入しているところあある ${ }^{19}$. 農場から搬入され た卵は農場・納入業者名, 数量, 重量などが確認された 後, 処理コンベアーベルトに乗せられ洗卵, 乾燥, 検卵 及び「鶏卵の取引規格 ل20) に基づいて選別・包装された 後, 出荷されている. GP センターにおける鶏卵の処理 工程と衛生的処理ポイント（啇正製造基準：GMP）を 図 2 に示す.

2) GP センター出荷後の鶏卵流通

GP センターで選別・包装されたパック（5１0 個 詰）卵は量販店や小売店に, 箱詰卵（ダンボール箱: $10 \mathrm{~kg}$ 詰め) やコンテナーに詰められた卵は，ホテルや 給食センターなどの飲食店や製菓・製パンあるいは惣菜 製造業などに配送される．また，箱詰又はコンテナーに 詰められた卵は, 卵包装（パック）工場及び割卵工場な ぞに送られ，そこでパック卵又は液卵にされるあのああ る. 更に，これらの箱詰卵，コンテナー詰卵は卵問屋を 経由して各ユーザーに配送されるあのなど種々の流通形 態（経路）がある（図 3).

，農場での卵生産から GP センターで処理され, 出荷さ
れるまでの経過日数は通常 1〜4 日間である. しかし, パック工場や卵問屋に配送された卵は，そこで更に 1 3 日間（卵価によっては更に数日間）保管される ${ }^{18)}$.

一般に, 量販店や小売店で販売され消費者に渡るのは 産卵後 1 週間以内であるが，更に長期間を要している あのああり, GP センター出荷後から数週間を経過した あのもある. また, 卵問屋を経由して割卵工場に搬入さ れるものでは 2 3 か月経過しているあのあ見られると 言われている.これらの卵流通は常温で行われており, この場合, 高温多湿環境下ではサルモネラ ( SE, S. Anatumなど) は, 卵殼を通過して卵内に侵入しやす いことが報告されており ${ }^{21)}, S E$ の污染及び増殖防止と しては, 低温 $\left(8^{\circ} \mathrm{C}\right.$ 以下) 流通の義務付けが必要であ $3^{15), 21 \text {. }}$

\section{2. 鶏卵の衛生管理}

1) 生産農場（採卵養䳕場）での衛生管理

殼付卵のサルモネラ（特にSE）污染には, SE 保菌 鶏の卵巣や卵管を経由して卵に移行し, 産卵時には既に 卵内に本菌か認められるむの (in-eggによる污染) と, 


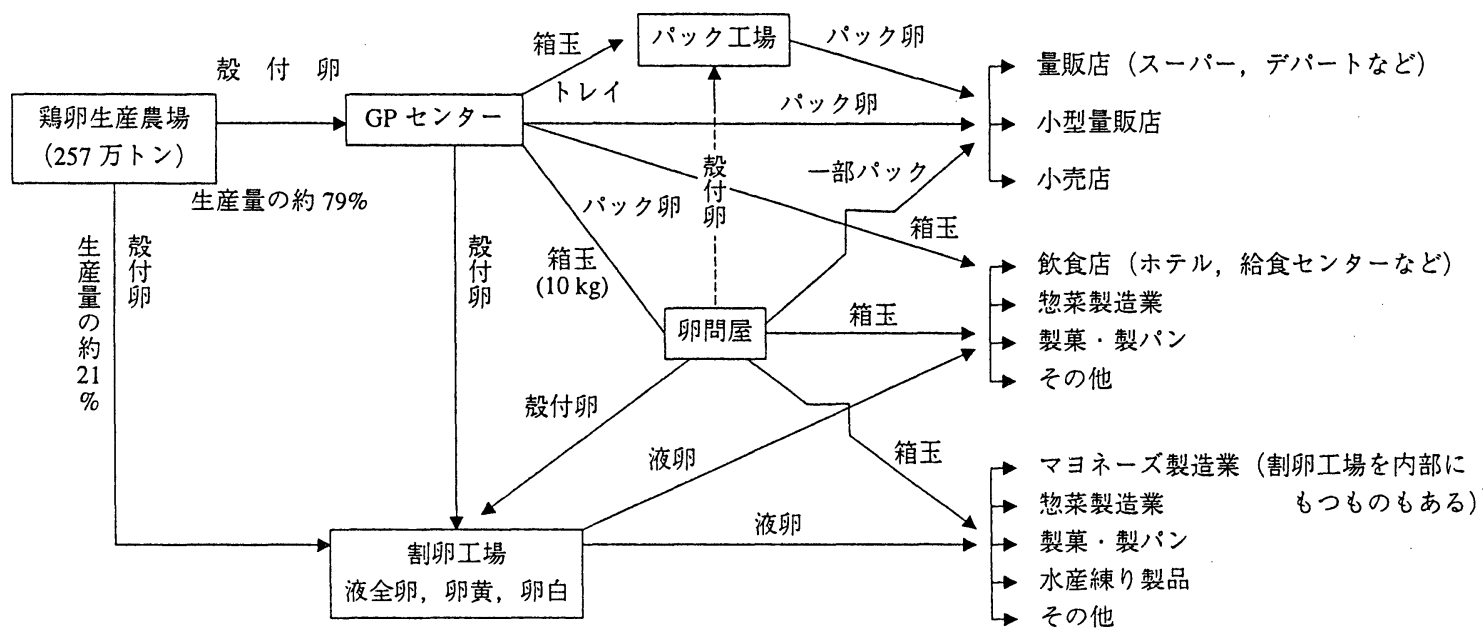

図 3. 䋨鳥卵の流通経路

産卵後卵殼表面に SE 污染粪便などが付着し，その後の 取り扱い, 処理・加工，流通時に卵款を通過し卵内に侵 入するあの (on-egg 污染) の二つの経路がある22) 24). しかし前者の污染は, SE 感染鶏であっても産卵される すべての卵に移行するむのではなく，一部の卵に低頻度 (1 羽当り $1.5 \sim 2.0 \%$ の頻度 $)^{25)}$ で污染し, その污染菌 数あ少ない（産卵後室温で 7 日間以内保存で $20 \mathrm{cfu} /$ 卵

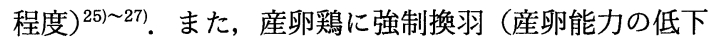
した鶏を一定期間断餌させて強制的に換羽させることに より，産卵能力を回復させる）によるストレス 22, 28), 29) や, 温度 (高温で鵎が熱射病を起こすような場合) ${ }^{30)}$ 及 び断水ストレス（一時的断水した時） ${ }^{31)}$ 等を与えること により, 排菌頻度は増加することあ報告されている. In-eggによる $S E$ 污染防止としては, 原種鶏や種鶏の 輸入時に SE 感染ヒナをチェックし，陽性ヒナを排除す ること, また種鶏場, 孵卵場及び採卵養鶏場における衛 生管理を十分行うことが重要である. 更に, 鷄舎管理 (ネズミもSE を保菌しており，その侵入防止） ${ }^{32)}$ や彩の 飼料管理等 ${ }^{33)}$ を十分行うことも必要である. 農林水産 省は生産農場におけるサルモネラ対策として, いくつか の衛生対策指針を作成し都道府県に通達を行ってい る ${ }^{34)}$. 採卵農場における $S E$ 制御のための衛生管理につ いて表 4 に示す.

他方, on-eggによる污染は, 産卵時に総排泄腔での 污染, 産卵直後のケージ及び GP センター（インライン 方式）輸送ベルトなどによる粪便污染によって, 卵殼表 面にサルモネラが付着し, その後の取り扱い不適によっ て卵内に侵入する ${ }^{35)}$ ，また，カルシウム含量の多い慨を 与えた卵（比重が大きく，卵殼の厚い卵）では，卵殼表 面のサルモネラの浸入性は低く ${ }^{36)}$, 更に卵を急激に冷却
表 4. 採卵農場における $S E$ の制御

1. 施設・設備の衛生管理

2. 衛生管理体制の確立 [衛生標準作業手順書 (SSOP) の作成]

3. 衛生管理基準 (CL) の設定（モニタリング法 を含む）

4. $\mathrm{CL}$ 逸脱時の措置方法の設定

5. 生菌剤・ワクチン等による鶏 $S E$ 排除

6. 導入ヒナ・・飼料の $S E$ 検查・管理

7. 養鶏場における衛生管理責任者の設定

8. SE 污染又は污染が疑われる卵の回収システム の設定

することにより卵内に容易に侵入することも明らかにさ れている37), 38). 我が国における殼付卵のサルモネラ污 染状況を表 5 に示す.

2） GP センターでの卵処理工程における衛生管理 生産農場から GP センターへ搬入される卵のグレード は, 污卵及び破卵の状態によって, 以下のように区別さ れる19).

正常卵：肉眼で卵款にヒビ様のあのが見えず, 糞便, 卵内容物, 血液及び羽毛などに污染されていない卵。

污卵 (soild egg): 粪便, 卵内容物, 血液, 羽毛などの 付着程度によって $\mathrm{A}$ 級 (付着が最も少ない), B 級及び $\mathrm{C}$ 級（付着が最も多い）污卵に区別される.

破卵 (hair line cracked egg): 破卵の程度によって下 記に示す $A \sim D$ 級に区別されている.

$\mathrm{A}$ 級破卵：肉眼的には正常卵と区別できないが，暗 所の透過光線下によってヒビ様のあのが見られる卵.

B 級破卵 (cracked egg): 卵款にヒビが入り肉眼で判 
表 5. 我が国における殼付卵のサルモネラ污染状況

\begin{tabular}{|c|c|c|c|c|}
\hline 検体 & 検查数 & 陽性数 & 血清型 & 調査年 \\
\hline 1. 全卵 & 3,285 & 7 & S. Oranienburg $(7)^{*}$ & 1971 \\
\hline 2. 卵壳 & 1,470 & 2 & S. Mbandaka, S. Braendrup & $1990 \sim$ \\
\hline 卵内容 & 1,470 & 1 & S. Braendrup & 1993 \\
\hline \multirow[t]{2}{*}{ 3. 卵黄・卵白 } & 2,400 & 0 & & \\
\hline & 24,000 & 6 & S. Enteritidis (6) & 1992 \\
\hline 4. 卵壳 & 6,700 & 10 & & 1993 \\
\hline 卵黄・卵白 & 6,700 & 1 & & 1994 \\
\hline 5. 卵黄・卵白 & 735 & 1 & S. Enteritidis & 1994 \\
\hline \multicolumn{5}{|l|}{ 6. 食中毒関連時の調査 } \\
\hline 卵殼 & 323 & 10 & S. Enteritidis (10) & 1993 \\
\hline 卵黄・卵殼 & 323 & 1 & $S$. Enteritidis & \\
\hline
\end{tabular}

*（）内は陽性検体数.

別できるが，卵殼膜は破れていない卵.

$\mathrm{C}$ 級破卵 (broken egg): 卵款及び卵款膜のいずれも破 れているが, 内容物は漏出していない卵.

$\mathrm{D}$ 級破卵 (leaker): 卵款, 卵款膜は破れ, 内容物が外 に漏出している卵.

軟卵：卵款が形成されず卵膜だけのもの.

血卵 (血玉)：卵中に血液の混入しているもの.

これらのうち, SE 污染防止には污卵 (B及びC 級) 及び破卵 (A〜C 級) の衛生的取り扱い（農場及び GP センターでの取り扱いと処理) が必要である.

次に, GP センターでの処理工程で, 微生物（サルモ ネラを含む）污染防止のための重要な衛生管理ポイント を以下に示す.

\section{(1) 搬入卵の管理}

一般に，生産農場（採卵養鶏場）では C 級污卵及び C, D 級破卵は区別して GP センターに搬入されており， 更に GP センターではエッグローダーで卵処理のベルト コンベアに乗せる場合にも，これらの污卵，破卵は区別 され, 別途処理又は廃棄されている. しかし, A 級破 卵及び A， B 級污卵 (中には C 級污卵) は, 正常卵之 一緒に処理されている. また, 農場直結型のインライン 式 GP センターでは, 産卵された卵は直接処理コンベ アーに移行しているため, 污卵, 破卵の区別はほとんど 行われていないのが現状である.

GP センターでの最初の衛生管理ポイントは, 搬入卵 の污卵・破卵を十分にチェックし, 処理ラインに持ち込 まないことである.

(2) 洗浄工程の管理

洗卵工程む重要な衛生管理ポイントの一つである．洗 卵は一般に $45 \sim 60^{\circ} \mathrm{C}$ の温水によるブラシ洗浄が行われ ているが, 洗浄水及び洗浄ブラシはサルモネラなどの微 生物污染が高いことも知られている ${ }^{19), 37)}$.

洗浄方法には, (1)水洗方式, (2)ドライ方式があり, 更 に前者には循環式（洗浄水を繰り返し使用する方式）と
ワンウエイ式（洗浄水は再使用しないで, 新しい湯水で 洗浄する方式）があり，後者のドライ方式は水を使用せ ず卵表面をブラシで清拭する方法である，米国では我が 国と同様に水洗方式が行われているのに対し，ヨーロッ パ諸国では污染の少ない卵はドライ方式が行われてお り, 污卵は割卵工場で温水洗浄後, 液卵に使用すること と定められている．米国USDA では，洗卵方法につい て洗卵水は $90^{\circ} \mathrm{F}\left(32.2^{\circ} \mathrm{C}\right)$ 以上で，少なくと屯卵品温よ り $6.7^{\circ} \mathrm{C}$ 以上の高い温水を用いること, 洗浄水は 4 時 間以内に 1 回以上交換し, 洗浄後は次塩素酸ナトリウ ム 50〜200 ppm の温水でシャワーリングすることと定 めている ${ }^{8}$.

我が国ではドライ方式による洗浄は，一部の施設で行 なわれているにすぎない.ほとんどの GP センターで は, 水洗方式のワンウエイ式が行われており, 都市近郊 の GP センター（大量処理している大型 GP センター） では，循環式を用いているところも見られる．循環式は 洗浄水を繰り返し使用するため, 卵款表面の污物（粪便 等）を除去して肉眼的に清潔にしても, 微生物学的には 污染を拡散しているにすぎない，特に，洗浄水温が低い $\left(50^{\circ} \mathrm{C}\right.$ 以下) 場合, サルモネラなどの病原菌は生残し， 多くの卵を污染させていることになる. それゆえ循環式 の場合, 一度使用した洗浄水は加熱などによって殺菌処 理したものを使用すること，及び卵洗浄後，消毒・殺菌 剤（次亜塩素酸ナトリウム溶液又は同等以上）を含む清 潔な温水でシャワーリングを行うことなどあ重要な衛生 管理ポイントである ${ }^{15)}$.

正常卵について, 無洗浄卵之洗浄卵（水洗方式：循環 式）を一定期間保存 $\left(25^{\circ} \mathrm{C}\right)$ した場合, 卵内の細菌数を 表 6 に示す. 卵を水洗洗浄することにより, 卵款表面 のクチクラ層が破壊され, 卵表面の污染細菌は卵殼を通 過しやすくなり, 洗浄卵は無洗卵に比べて短期間で菌数 増加を示すあのあ多く認められるようになる. 更に, SE の卵款通過による卵内侵入性について, 品温の高い 
表 6. 正常卵（無洗浄卵之洗浄卵）の保存中における生菌数の変化

一無洗浄卵一

\begin{tabular}{|c|c|c|c|c|c|c|}
\hline \multirow{2}{*}{ 生菌数 /g } & \multicolumn{6}{|c|}{ 卵の保存*（週)：生菌数を示す卵個数 (\%) } \\
\hline & 0 & 1 & 2 & 3 & 4 & 6 \\
\hline 0 or $<10$ & $98(89.1)$ & $95(87.4)$ & $79(71.8)$ & $74(67.3)$ & $55(55.0)$ & $5(10.0)$ \\
\hline $10^{1} \sim 10^{2}$ & $12(10.9)$ & 15 (13.6) & 15 (13.6) & $19(17.3)$ & $26(26.0)$ & $10(20.0)$ \\
\hline $10^{2} \sim 10^{3}$ & - & - & $16(14.6)$ & 15 (13.6) & $16(16.0)$ & $22(44.0)$ \\
\hline $10^{3} \sim 10^{4}$ & - & - & - & $2(1.8)$ & $3(3.0)$ & $3(6.0)$ \\
\hline $10^{4} \sim 10^{5}$ & - & - & - & - & - & - \\
\hline$>10^{6}$ & - & - & - & - & - & - \\
\hline 合計 & $110(100 \%)$ & $110(100 \%)$ & $110(100 \%)$ & $110(100 \%)$ & $100(100 \%)$ & $50(100 \%)$ \\
\hline \multicolumn{7}{|c|}{ 一洗浄卵一 } \\
\hline \multirow{2}{*}{ 生菌数 /g } & \multicolumn{6}{|c|}{ 卵の保存（週)：生菌数を示す卵個数 (\%) } \\
\hline & 0 & 1 & 2 & 3 & 4 & 6 \\
\hline 0 or $<10$ & $94(85.5)$ & $89(80.9)$ & $76(76.0)$ & $58(52.7)$ & $50(50.0)$ & - \\
\hline $10^{1} \sim 10^{2}$ & $16(14.5)$ & $13(11.8)$ & $12(12.0)$ & $20(18.2)$ & $26(26.0)$ & $5(25.0)$ \\
\hline $10^{2} \sim 10^{3}$ & - & $6(5.5)$ & $10(10.0)$ & $16(14.6)$ & $12(12.0)$ & $7(35.0)$ \\
\hline $10^{3} \sim 10^{4}$ & - & $2(1.8)$ & $1(1.0)$ & $9(8.2)$ & $8(8.0)$ & $4(20.0)$ \\
\hline $10^{4} \sim 10^{5}$ & - & - & $1(1.0)$ & $2(1.8)$ & $2(2.0)$ & $2(10.0)$ \\
\hline $10^{5} \sim 10^{6}$ & - & - & - & $3(2.7)$ & $1(1.0)$ & - \\
\hline $10^{6} \sim 10^{7}$ & - & - & - & $2(1.8)$ & $1(1.0)$ & $2(10.0)$ \\
\hline $10^{7} \sim 10^{8}$ & - & - & - & - & - & - \\
\hline$>10^{8}$ & - & - & - & - & - & - \\
\hline 合計 & $110(100 \%)$ & $110(100 \%)$ & $100(100 \%)$ & $110(100 \%)$ & $100(100 \%)$ & $20(100 \%)$ \\
\hline
\end{tabular}

正 常 卵：肉眼で卵款にヒビ様のものが見えず, 糞便, 血液, 卵内容物等により污染されていない卵.

* 保存条件： $25^{\circ} \mathrm{C}$ 乾燥条件.

表 7. サルモネラ菌液と卵の温度別の浸漬による 卵内への侵入性*1

\begin{tabular}{|c|c|c|c|c|c|c|c|}
\hline \multirow{3}{*}{\multicolumn{2}{|c|}{$\begin{array}{l}S E \text { 菌液 } \\
\text { 温度 }\left({ }^{\circ} \mathrm{C}\right)\end{array}$}} & \multicolumn{3}{|c|}{ 卵温度 $\left(10^{\circ} \mathrm{C}\right)$} & \multicolumn{3}{|c|}{ 卵温度 $\left(40^{\circ} \mathrm{C}\right)$} \\
\hline & & \multicolumn{2}{|c|}{ 保存期間*2 } & \multirow{2}{*}{$\frac{\text { (週) }}{3 \text { 週 }}$} & \multicolumn{3}{|c|}{ 保存期間（週） } \\
\hline & & 0 週 & 1 週 & & 0 週 & 1 週 & 3 週 \\
\hline \multirow{4}{*}{$\begin{array}{l}\text { 正 } \\
\text { 常 } \\
\text { 卿 }\end{array}$} & 5 & $0 * 3$ & 3 & 8 & $3^{* 4}$ & 3 & 5 \\
\hline & 10 & 0 & 1 & 7 & 2 & 4 & 5 \\
\hline & 20 & 0 & 2 & 4 & 0 & 3 & 5 \\
\hline & 30 & 0 & 2 & 4 & 0 & 3 & 5 \\
\hline
\end{tabular}

*1 サルモネラ菌液：S. Enteritidis, $10^{5} \mathrm{cfu} / \mathrm{mL}$ 浸漬時間：10 分.

$* 2$ 卵保存: $25^{\circ} \mathrm{C}$, 乾燥状態.

*3 卵 10 個検査したときの SE 陽性個数.

*4 卵 5 個検査したときの $S E$ 陽性個数.

卵を低温の $S E$ 菌液に浸漬した場合, SE の侵入性は高 くなる（表 7)。 また，正常卵と $\mathrm{A}$ 級破卵を $S E$ 菌液に 浸漬後, 一定温度 $\left(25^{\circ} \mathrm{C}\right)$ で保存した場合, 卵内の $S E$ 污染を調べると, 破卵（A, B 級）では侵入性が高く，
しかあ污染菌数の多いあのあ認められた（表 8,9）. 同 様に, 卵款表面に $S E$ 污染糞便を付着させて保存した場 合でも，A 級破卵では正常卵に比べ容易に卵内に侵入 した ${ }^{21)}$. GP センター及び割卵工場で卵洗浄に使用され る消毒剂として, 第 3 リン酸ナトリウム, 次亜塩素酸 ナトリウム（有機物の付着が多い場合, 効力は減少）は 効果があり ${ }^{39)}$, 卵洗浄後のシャワーリング水にこれらの 消毒剤を添加することはサルモネラ侵入防止に有効であ る.

\section{(3) 検卵工程}

GP センターでの検卵工程は, 卵の衛生監視・管理を 行う上で最あ重要なポイントである.この工程で破卵, ヒビ入り卵（キズ卵む含む）, 糞便・血液などの污卵 （シミ卵を含む），血卵（血玉）などが選別されており， ここで検定合格になった卵はそのまま重量選別後包装さ れ, 加工, 流通, 販売等を経由して消費される. 検卵で は $\mathrm{A} \sim \mathrm{D}$ 級破卵並びに污卵を確実に選別し，更に卵の 乾燥状態の確認等を行い，これらの不適卵を排除するこ とが重要である，それゆえ，この検卵者は衛生管理につ 
表 8. サルモネラ菌液浸漬による卵内への侵入性*1

\begin{tabular}{rcccc}
\hline \hline \multirow{2}{*}{ 卵グレード } & \multicolumn{4}{c}{ 保存温度 $\left(25^{\circ} \mathrm{C}\right)$ ・期間 $($ 日) } \\
\cline { 2 - 5 } & 0 日 & 3 日 & 7 日 & 14 日 \\
\hline 正常卵 & $1^{* 2}$ & 3 & 7 & 10 \\
$\mathrm{~A}$ 級破卵 & 4 & 6 & 10 & 10 \\
$\mathrm{~B}$ 級破卵 & 9 & 9 & 10 & $\mathrm{NT}^{* 3}$ \\
\hline
\end{tabular}

*1 浸漬卵: $25^{\circ} \mathrm{C}$, サルモネラ 菌液: $S$. Enteritidis, $10^{6} \mathrm{cfu} / \mathrm{mL}, 10^{\circ} \mathrm{C}$, 浸漬時間： 10 分.

*2 卵 10 個検査したときの SE 陽性個数.

*3 NT：検查せず.

いて十分な知識を有する者，または専任者（鶏卵処理衛 生管理者）を配置すべきである。

\section{III. 加 工 卵}

加工卵とは，殼付卵を割卵（自動割卵機又は手割りで 割卵）して液卵としたもの（液全卵），卵黄と卵白に分 離して液卵としたもの，更にこれらに糖又は食塩などを 添加したあのであり，これらをチルド（液全卵を対象）, 凍結あるいは乾燥（我が国ではほとんど製造されていな い）などの一次加工を行ったもので, 商業的に取引され る製品をいう ${ }^{40)}$. 各液卵の製造工程と衛生管理 (GMP) を図 4 に示す。これらの製品はそのままの形状で消費 者に提供されることはなく, 調理, 加工 (二次加工) 用 として用いられる. 加工卵は大手の食品加工業社の製 菓・製パン, 水産練製品, 畜肉加工, 制菜などの製造に 使用されるもので, 小規模の旅館, 食堂, 給食場などで はほとんど使われない.

\section{1. 液卵の衛生管理}

我が国における未殺菌液卵のサルモネラ污染は, 報告 者, 調查年・時期（季節）によって異なるが, 10 $80 \%$ と高いことが報告されている $\left.{ }^{40)}, 41\right)$. 本菌は液全卵 及び卵黄中で, $5^{\circ} \mathrm{C}$ では増殖しないが, $10^{\circ} \mathrm{C}$ ではわず かに増殖を示す ${ }^{40)}$. また, 冷蔵や冷凍状態では長期間生 存し, 不適当な温度下に置かれた場合に増殖を示す。 そ れゆえ，液卵製造に当たっては原卵受け入れから製造・ 加工及び製品保管まで, 十分な衛生管理を行うことが重 要である.

厚生省では，「卵及びその加工品の衛生対策について」 (平成 4 年 7 月 8 日, 衛乳第 128 号) の中で, その取り 扱い方を定め, 各都道府県, 政令市及び特別区に対し通 知している. その主な内容は次のとおりである.

ア）破卵及びヒビ割れ卵（B 級破卵）は細菌の污染を 受けやすいので，速やかに冷蔵するととあに長期 間経過しないうちに加熱して使用, 加工するこ 之.

イ）液卵は加熱殺菌したものを使用するか，または加 工もしくは調理の過程で加熱殺菌すること. 液卵 の保存及び流通にあたっては，冷蔵及び冷凍する
表 9. サルモネラ菌液浸漬による卵内中の菌数*1

\begin{tabular}{|c|c|c|c|c|c|}
\hline \multirow{2}{*}{ 卵グレード } & \multirow{2}{*}{ 卵 No. } & \multicolumn{4}{|c|}{ 保存温度 $\left(25^{\circ} \mathrm{C}\right) \cdot$ 期間（日） } \\
\hline & & 0 日 & 3 日 & 7 日 & 14 日 \\
\hline \multirow[t]{5}{*}{ 正常卵 } & 1 & $0^{* 2}$ & 0 & 2 & 1,200 \\
\hline & 2 & 8 & 0 & 16 & 2 \\
\hline & 3 & 0 & 2 & 25 & 5 \\
\hline & 4 & 0 & 16 & 0 & 1 \\
\hline & 5 & 0 & 0 & 150 & 1 . \\
\hline \multirow[t]{5}{*}{ A 級破卵 } & 1 & 2 & 2 & 0 & \\
\hline & 2 & 1 & 2,700 & 61,000 & $\mathrm{NT}^{* 3}$ \\
\hline & 3 & 8 & 5,800 & 12 & \\
\hline & 4 & 3,200 & 0 & 190 & \\
\hline & 5 & 0 & 1,700 & 5 & \\
\hline
\end{tabular}

*1 浸漬卵： $25^{\circ} \mathrm{C}$, サルモネラ菌液：S. Enteritidis, $10^{6} \mathrm{cfu} / \mathrm{mL}, 10^{\circ} \mathrm{C}$, 浸清時間: 10 分.

$* 2$ 卵中身 $25 \mathrm{~g}$ 中の $S E$ 菌数.

$*^{3} \mathrm{NT}$ : 検査せず.

$$
\text { こと. }
$$

ウ）正常殻付卵は新鮮なうちに使用すること．やむを 得ず長期保存する場合は冷蔵保存すること.

エ）生卵，半生卵及びこれらを含む食品は，室温に長 時間置かないこと.

しかし，これらの通知後も卵及びその加工品によるサ ルモネラ $(\mathrm{SE})$ 食中毒が多発するため, 厚生省は「液卵 の製造などに係わる衛生確保について」(平成 5 年 8 月 27 日，衛乳第 160 号)，液卵製造施設等における衛生 指導要領を通知した.この衛生指導要領は，1) 目的, 2) 用語の定義，3) 原料卵，4）製造，5）製品及び 6) 液 卵の使用上の注意, の 6 項目から構成されており, 更 に 1) 洗卵における洗浄水の透視度測定法, 2) 液卵の微 生物基準における試験法, 及び殺菌前の液卵を 2 時間 以上眝蔵する場合に遵守すべき保存温度についても記述 されている. 以下, 液卵製造施設における衛生指導要領 のうち, 衛生管理を行う上に重要な項目について説明す る(表 10).

1) 原料卿

液卵に用いる原料卵について，(1) 原料卵の受け入れ， (2) 原料卵の運搬用器具，(3) 原料卵の保存, に分けて規 定されている. 破卵, 污卵及び軟卵は搬入後 24 時間以 内に割卵するか, 又は $8^{\circ} \mathrm{C}$ 以下で保存して 72 時間以内 に割卵して加熱殺菌すること. また, 正常卵を長時間保 存する場合でも $8^{\circ} \mathrm{C}$ 以下で保存し, 速やかに割卵する こととと義務づけられている.

2) 製造

製造は，(1) 洗卵工程，(2) 割卵及びろ過工程，(3) 殺 菌前の液卵の貯蔵温度, (4) 殺菌, 冷却及び充てん，(5) 無殺菌液卵，熱殺菌液卵（製品）に分けて規定されてい る.この内, (1)の洗卵工程では, 洗卵は飲用適の流水 


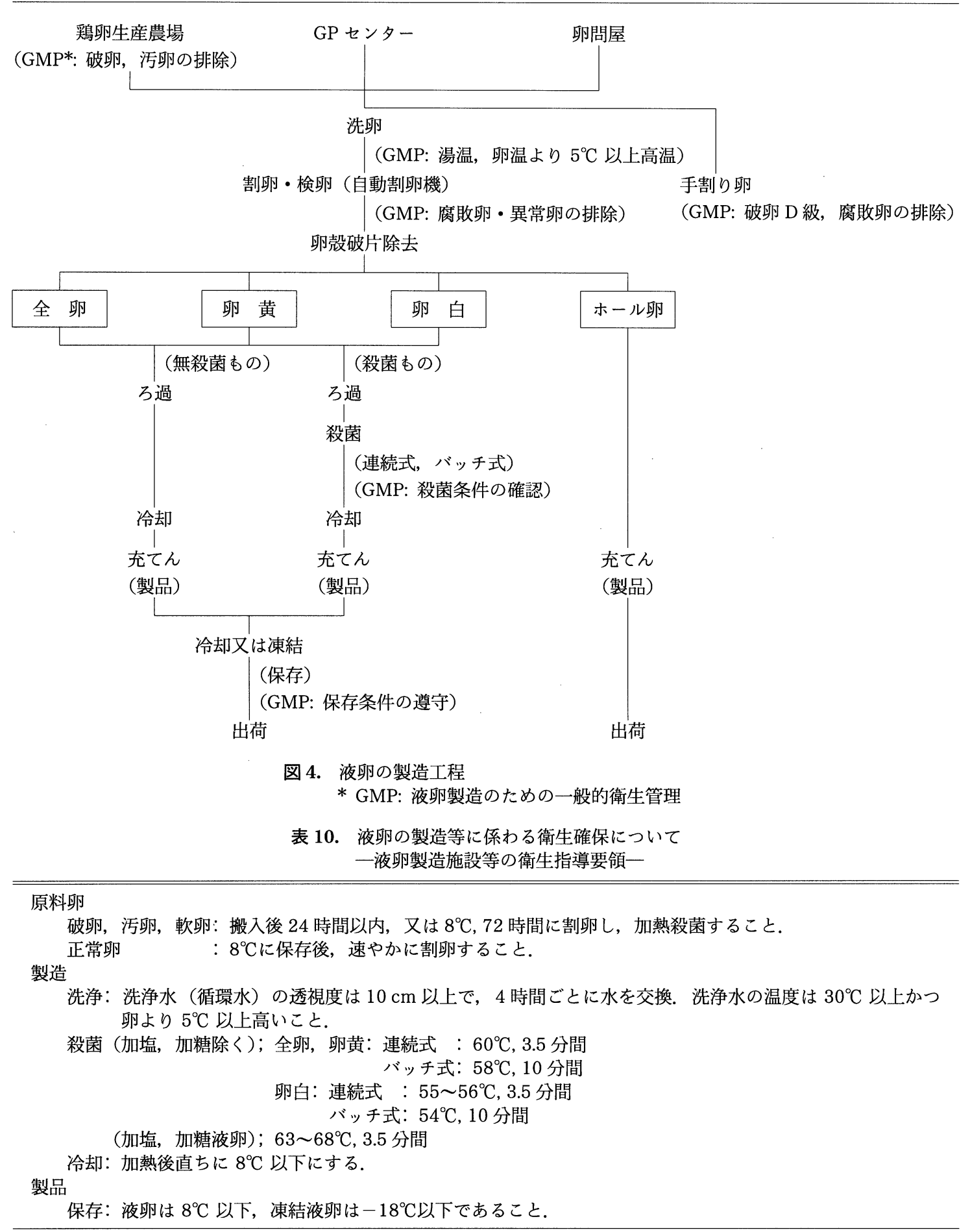

厚生省衛乳第 160 号. 
で行うこと, 循環水を使用する場合, 洗浄水の透視度は $10 \mathrm{~cm}$ 以上に保っとともに, 4 時間ごとにすべて新しい 水之交換すること. また洗浄水の温度は, $30^{\circ} \mathrm{C}$ 以上か つ原料卵の温度より $5^{\circ} \mathrm{C}$ 以上高くすることと定めてい る. (2) の割卵には, 機械割りと手割りがあり, 前者で はオペレータが割卵後の状態を検查し, 腐敗卵などの異 常卵を排除している。しかし, 割卵スピードが速いため (約 400 600個/分), 異常卵を見落とさないことが衛 生管理上重要である。 また，この異常卵を排除した後の 受卵カップは洗浄・消毒できる構造とすること（4)の 液卵の殺菌, 冷却及び充てんについて, 液卵の殺菌温度 は以下のように規定されている。

(1)加糖又は加塩したものを除く液卵では, 連続式殺菌 を行う場合, 液全卵及び卵黄は $60^{\circ} \mathrm{C} \cdot 3.5$ 分間, 卵 白は $55 \sim 56^{\circ} \mathrm{C} \cdot 3.5$ 分間とし, バッチ式殺菌を行う 場合, 液全卵及び卵黄は $58^{\circ} \mathrm{C} \cdot 10$ 分間, 卵白は $54^{\circ} \mathrm{C} \cdot 10$ 分間であることと定められている.

(2)加糖又は加塩した液卵では, 連続式殺菌を行い, 加 糖又は加塩の濃度により $63 \sim 68^{\circ} \mathrm{C} \cdot 3.5$ 分間である ことと定められている.

なお殺菌前, 液卵を 2 時間以上貯蔵する場合に遵守 すべき温度についてあ規定され, 更に冷却についても, 加熱後直ちに $8^{\circ} \mathrm{C}$ 以下にすることが定められている.

3) 製品

製品の保存は, 液卵では $8^{\circ} \mathrm{C}$ 以下, 凍結液卵では

表 11. 液卵（製品）の微生物基準

\begin{tabular}{clcccc}
\hline \hline 製品 & 検查対象微生物 & $\mathrm{n}$ & $\mathrm{c}$ & $\mathrm{m}$ & $\mathrm{M}$ \\
\hline 無殺菌液卵 & 細菌数 (生菌数) & 5 & 3 & $10^{4}$ & $10^{5}$ \\
(製品) & 大腸菌群 & 5 & 2 & $10^{1}$ & $10^{2}$ \\
\hline 加熱殺菌液卵 & 細菌数 (生菌数) & 5 & 2 & $10^{4}$ & $10^{5}$ \\
(製品) & 大腸菌群 & 5 & 1 & $10^{1}$ & $10^{2}$ \\
\hline
\end{tabular}

$\mathrm{n}:$ 検査サンプル個数

$\mathrm{c}$ : 合格判定個数 (ロットを合格と判定する基準：m $\sim \mathrm{M}$ の個数)

$\mathrm{m}$ : 合格判定值（合格判定菌数值： $\mathrm{cfu} / \mathrm{g}$ )

$\mathrm{M}$ : 条件付き合格と判定する基準（許容限界菌数： $\mathrm{cfu} / \mathrm{g}$ ) $-18^{\circ} \mathrm{C}$ 以下と規定されている。 また，液卵（無殺菌液 卵，加熱殺菌液卵）の微生物基準が設けられ，これは ICMSF (The International Commission on Microbiological Specification for Food: 国際微生物規格委員 会）が提案している国際食品微生物規格に示されている 三階級法 (n, c, m, M) の考元方が採用されている ${ }^{42)}$. 液 卵（製品）の微生物基準は表 11 のとおりである.

4）液卵の使用上の注意

食品などの取り扱いの中では，下記に示す項目が衛生 管理を行う上に重要である。

(1) 液卵は $8^{\circ} \mathrm{C}$ 以下（凍結液卵においては $-18^{\circ} \mathrm{C}$ 以下）で保存すること。

（2）液卵を原材料として食品を製造する場合，十分 加熱を行うことを原則とする. しかし，製造又は調 理の過程で加熱が行われない場合には，加熱殺菌済 みの液卵を用いること。

（3）卵焼きなどの加熱調理を行った「卵加工品」に ついては, 微生物基準が次のように設けられてい る.

$$
\begin{aligned}
& \text { 細菌数 (生菌数): 検体 } 1 \mathrm{~g} \text { 当り } 10^{5} \text { 以下 } \\
& \text { 大腸菌 }(E . \text { coli }) \text { : 陰性 } \\
& \text { サルモネラ：陰性 }
\end{aligned}
$$

（4）液卵及び凍結液卵を原材料として製造した製品 は，製造ロットごとに製品 1 個を検食として，販 売期間などを考慮して， $10^{\circ} \mathrm{C}$ 以下で保存すること. 以上に示した液卵製造施設での衛生指導要領は, 液卵 製造及び使用上における重要な衛生管理ポイントであ り, 安全で衛生的な液卵を製造するためにはこれらを確 実に実施すべきである.

\section{IV． 卵及び卵加工品によるサルモネラ食中毒防止対 策}

卵及び卵加工品による $S E$ 食中毒を防止するため，食 品衛生調查会・乳肉水産食品・食中毒合同部会では「卵 によるサルモネラ食中毒の発生防止について」の報告書 をまとめている(平成 9 年 12 月 5 日) ${ }^{15}$. . 本報告の中 で, まず最初に「卵及び卵加工品の衛生対策の基本的な 考え方」を提示し（表 12), 次に具体的な衛生対策とし て「款付卵」「液卵」及び「家庭における卵の衛生的な 取り扱い」に区別してまとめており，最後にこれらの衛

表 12. 卵及び卵加工品の衛生対策の基本的な考え方

\footnotetext{
1. 卵および卵加工品によるサルモネラ食中毒の防止として, 生産（農場）から消費に至るまでの各段階におけ る污染防止，増殖抑制および死滅操作等の対策を確実に行う。

2. わが国では生卵を喫食する習慣があり，これを前提とした衛生対策が必要である.

3. 生食用の殼付き卵を除いて, 卵加工・調理食品については消費者に提供されるまでの間に, いずれかの段階 で必ずサルモネラを死滅させるための加熱工程を導入する.

4. 食品の製造者や消費者に対して, 卵の表示を義務付けて, 適切に卵を取り扱うための情報を提供する.

5. 消費者の役割を明確にし, 家庭における卵の適切な取り扱い方法について積極的な啓発を行う.
} 
表 13. 鶏卵の加工・調理における SE の動態

耐熱性：全卵, 卵黄中で $60^{\circ} \mathrm{C}, 3.5$ 分 $\left(65^{\circ} \mathrm{C}, 3\right.$ 分) で死滅. 卵白中で $55^{\circ} \mathrm{C}, 3.5$ 分 $\left(56^{\circ} \mathrm{C}, 2 \sim 3\right.$ 分) では死滅. 砂糖や 食塩を添加すると耐熱性は增加. 食品中では $68^{\circ} \mathrm{C}, 3.5$ 分で死滅.

增殖温度： $10^{\circ} \mathrm{C}$ 以下, $46^{\circ} \mathrm{C}$ 以上で増殖遅延. $5^{\circ} \mathrm{C}$ 以下及び $50^{\circ} \mathrm{C}$ 以上では増殖しない.

增殖 $\mathrm{pH}$ : $\mathrm{pH} 10$ 以上又は 4.75 以下では増殖しない。 $\mathrm{pH} 4.0$ のマヨネーズ中で生存. $\mathrm{pH} 4.6$ で増殖する。 $\mathrm{pH} 3.0$ $\sim 3.5\left(23^{\circ} \mathrm{C}\right)$ で死滅.

増殖 $a_{\mathrm{w}}: a_{\mathrm{w}} 0.95$ 以下では增殖しない.

消毒剂耐性：食品製造所で使用される通常の消毒剤は有効.

凍＼cjkstart結：食品中の SE は凍結では死滅しない.

乾 燥：食品中の SE は乾燥に対して生残，しかし増殖はしない，乾燥するまでの間に増殖することあり．

卵食品を水で希釈：非常に薄い希釈液中でも増殖.

生対策を早急に実施し，サルモネラ食中毒の発生防止を 図るべきであると締めくくっている.

\section{1. 殼付き卵の衛生対策}

款付き卵の $S E$ 対策として，1) 生産段階における対 策，2) 流通段階一GP センター，食品製造所・飲食店等 一における対策，及び 3) 消費者における対策に分けて， それぞれ述べられている.

1）生産段階における対策として，(1) 採卵養鶏場の サルモネラ防除の徹底, (2) 輸入七ナの検疫強化, (3) $\mathrm{SE}$ ワクチン等の有効利用, (4) 卵によるサルモネラ食 中毒発生時の採卵養䳕場までの「逆のぼり調査」への協 力, (5) 重度破卵, 餒化中止卵の食用禁止の徹底等を挙 げ,これらの対策について早急に実施するよう農林水産 省に要請している.

2) 流通段階における対策として, 採卵農場及び GP センターの所在, 名称 ・ 氏名の表示, 及び (1) 消費期限 又は品質保持期限, (2) 購入後の冷蔵保管の必要性, (3) 生食用及び加熱・加工用の区別をすること．また, 卵加 工・調理食品の場合, 割卵後速やかに $70^{\circ} \mathrm{C}, 1$ 分以上又 はこれと同等の加熱殺菌をすることと述べている. 卵加 工及び調理食品の $S E$ コントロールを行うためには，本 菌の性状・動態（表 13）を十分に把握しておく必要が ある.

3）消費者における衛生対策として，(1) 卵はきれい で,ひび割れのない新鮮なむのを購入. (2) 購入後, 早 急に冷蔵庫に入れる. (3) 加熱調理では十分に加熱する. (4) 卵を生で食べる場合, 破卵やひび割れ卵を使用しな い．食べる直前に割卵する．(5) 卵料理は調理後 2 時間 以内に食べること等について提案している8

\section{2. 液卵の衛生対策}

殺菌液卵及び未殺菌液卵について，成分規格（サルモ ネラ：食品 $25 \mathrm{~g}$ 中陰性）及び製造基準［原料卵の保存 (温度と時間) 条件, 洗卵, 割卵，万過工程及び殺菌等 の各条件］の設定, 更に製品の保存基準, 表示等を定め ている，液卵の衛生管理（SE 対策）としては，これら の基準を遵守することにより，SE 食中毒の発生を防止 することが望まれる。

\section{3. 家庭における卵の衛生的な取り扱い}

家庭で卵を取り扱う際のポイント（購入，保存，下準 備, 調理, 食事及び残品の 6 項目) についてあ詳細に 述べられている，安全で衛生的な卵を摂取するために は，消費者が各自十分な注意を払って取り扱う（消費者 の責任）ことも重要である.

最近，厚生省の「鶏卵の日付け表示」に関する検討委 員会は，生食用殼付卵の「期限表示」について最終報告 を示した ${ }^{43)}$. 賞味期限は，卵黄膜が軟化してサルモネラ 等の食中毒菌が異常に増殖するまでの期間に基づいて算 出されている。実際に鵎卵の生食可能な期限（日）設定 には，農場から GP センターに搬入される期間，GP セ ンターで処理・保管される期間及び流通・保管（販売） 期間の「各温度と日数」から算出される ${ }^{43)}$. 更に, これ らの日数に家庭などでの冷蔵庫保管期間（7日間）を加 えて最終的な生食可能な期限が求められる。この期限設 定を行うには，夏・冬期の季節により大きく異なり，卵 の生産，GP センターでの処理，流通及び販売等の各工 程期間の温度，日数等を，記録し保存しておくことが重 要である。

今後, 卵及び卵加工品におけるサルモネラ等の食中毒 菌污染を防止し, 卵の安全性を確保するためには, 鶏卵 農場から消費者まで一貫した衛生管理が必要であり, 各 段階における GAP（適正農畜産物生産基準）や GMP （適正製造基準）及び SSOP（衛生的標準手順書）等を 構築することが重要であると考えられる.

\section{文献}

1) Duguid, J. P., North, R. A. E.: J. Med. Microbiol. 34, 65 $\sim 72$ (1991).

2) Rodrigue, D. C., Tauxe, R. V., Rowe, B.: Epidemiol. Infect. 105, 21 27 (1990).

3）厚生省生活衛生局食品保健課：昭和 62,63 年全国食中毒 事件録, p. 84 98 (1991).

4) 小沼博隆, 品川邦汎, 熊谷 進: モダンメディア 41, 230 244 (1995).

5) JAVMA: JAVMA, 196, 850 (1990).

6) Anon: Report of WHO consultation on epidemiolo- 
gical emergency in poultry and egg-salmonellosis. 20-23, Geneva, WHO (1989).

7）中村政幸：鶏病研究 25, 127～131, 184 191 (1989).

8）厚生省生活衛生局乳肉衛生課：食品衛生調查会 乳肉水 産食品部会資料, 7 月 23 日 (1997).

9) Euro Surveillance: Euroroundup 2 January, France (1997).

10）国立予防衛生研究所：病原微生物検出情報 18(3), 51 53 (1997).

11）中村明子：臨床と微生物 23(6), 107 112 (1996).

12) Rodrigue, D. C., et al.: J. Clin. Microbiol. 30, 854 857 (1992).

13）中村明子：LABEAM（SRL 感染症検査ニューズレター） 9(9), 1 3 (1997).

14）伊藤 武, 楠 淳: 動薬研究 53, 1 11 (1996).

15）食品衛生調查会 乳肉水産食品・食中毒合同部会：卵に よるサルモネラ食中毒の発生防止について, 報告書 12 月 5 日 (1998).

16) 三重県桑名保健所：地域食品保健推進事業（平成 8 年 度）“サルモネラ食中毒の防止対策” (1998).

17) Blaser, M. J., Newman, L. S.: Rev. Infect. Dis. 4, 1,096 $\sim 1,106$ (1982).

18) Glynn, J. R., Bradly, D. J.: Epidemiol Infect. 109, 371 388 (1992).

19) 增田高志, 小沼博隆, 品川邦汎：日食微誌. 10, 203 210 (1994).

20）中央鶏卵規格取引協議会：鶏卵規格取引ガイドブック, p. $1 \sim 21,10$ 月 (1974).

21) Simmons, E.R., et al:: Poultry Sci. 49, 761 768 (1970).

22）佐藤静夫：日食微誌. 10, 185 193 (1994).

23) Snoeyenbos, G. H., et al:: Avian Dis. 13, 668 670 (1969).
24) Nakamura, M., et al.: J. Vet. Med. Sci. 55, 649 665 (1963).

25) Humphrey, T. J., et al.: Epidemiol. Infect. 103, 415 423 (1989).

26) Mawer, S. L., et al.: Lancet 280 281 (1989).

27) Humphrey, T. J., et al.: Epidemiol. Infect. 106, 489 496 (1991).

28) Holt, P. S., Porter, Jr. R. E.: Avian Dis. 36, 610 618 (1992).

29) Holt, P. S.: Avian Dis. 37, 412 417 (1993).

30) Jones, F. T.: Feed Stuff. 64(11), 22 23 (1992).

31) Brownell, J. R., et al.: Avian Dis. 13, 804 816 (1969).

32) Henzler, D. J., Opitz, H. M.: Avian Dis. 36, 625 631 (1992).

33) Hilton, M., et al:: Vet. Rec. 124, 223 (1989).

34) 鶏病研究会：鷄卵・鶏肉のサルモネラ全書 p. 257 280 (1998).

35) Board, R. G., et al:: Poultry Sci. 43, 584 595 (1964).

36) Sauter, E. A., Petersen, G. F.: Poultry Sci. 53, 2,159 2,162 (1974).

37) 小沼博隆, 品川邦汎: 鶏病研究会報 30, 79 86 (1994).

38) Hopper, S. A., Mawer, S.: Vet. Rec. 123, 351 355 (1988).

39) 後藤公吉ら：食衛誌. 37, 165 172 (1996).

40) 今井忠平, 栗原健志：鷄卵肉情報 2 月 25 日 7 月 25 日 (1995).

41) 村瀬 稔: モダンメディア 40(7), 3〜10 (1994).

42）倉田 浩ら：“食品衛生における微生物制御の基本的な考 え方”p. 36 51 (1994) 日本食品衛生協会.

43）渡辺邦雄：鶏卵肉情報 10 月 25 日号 (1998). 